University of Rhode Island

DigitalCommons@URI

2016

\title{
Social Media, Public Discourse and Civic Engagement in Modern China
}

Yinjiao Ye

University of Rhode Island, yinjiao_ye@uri.edu

Ping Xu

University of Rhode Island, pingxu@uri.edu

Mingxin Zhang

Follow this and additional works at: https://digitalcommons.uri.edu/psc_facpubs

The University of Rhode Island Faculty have made this article openly available.

Please let us know how Open Access to this research benefits you.

This is a pre-publication author manuscript of the final, published article.

Terms of Use

This article is made available under the terms and conditions applicable towards Open Access

Policy Articles, as set forth in our Terms of Use.

Citation/Publisher Attribution

Ye, Yonjiao, et al. "Social media, public discourse and civic engagement in modern China." Telematics and Informatics, vol. 34, no. 3, 2017, pp. 705-714. http://dx.doi.org/10.1016/j.tele.2016.05.021

Available at: http://dx.doi.org/10.1016/j.tele.2016.05.021

This Article is brought to you for free and open access by the Political Science at DigitalCommons@URI. It has been accepted for inclusion in Political Science Faculty Publications by an authorized administrator of DigitalCommons@URI. For more information, please contact digitalcommons@etal.uri.edu. 
Social Media, Public Discourse and Civic Engagement in Modern China

\author{
Yinjiao Ye \\ Department of Communication Studies \\ University of Rhode Island \\ Email: yinjiao_ye@uri.edu
}

\author{
Ping $\mathrm{Xu}$ \\ Department of Political Science \\ University of Rhode Island \\ Email: pingxu@uri.edu
}

Mingxin Zhang

School of Journalism and Communication

Huazhong University of Science \& Technology

mingxinzhang@hust.edu.cn 


\begin{abstract}
Drawing on the theoretical view of cyberspace's role in engagement in public discourse and civic activities, the current study investigates how social media use is related to public discourse and civic engagement in mainland China. Moreover, we examine how political interest, general trust in people, and life satisfaction modify the interdependence of social media use and public discourse and civic engagement. Data analyses based on a survey of 1, 202 online Chinese show that social media use is significantly related to both public discourse and civic engagement. In addition, political interest has a consistent, strong modification on the role of social media use in public discourse and civic engagement. Both general trust in people and life satisfaction moderate some of the relationships examined but not all of them. Theoretical and empirical implications of the results are discussed.
\end{abstract}

Keywords: Social media; public discourse; civic engagement; political interest; general trust; life satisfaction 
Civil society is commonly referred to as "the intermediate public realm between the state and the private sphere” and includes any "organized or unorganized, discursive or non-discursive activities” that happen in this public sphere ${ }^{1}$ (Yang, 2003, p. 406). Such an independent public sphere was nearly non-existent during the Maoist era because of the dominant party state and strict restrictions on associational lives (Jennings, 1997; Yang, 2007). Yet, scholars argue that the capitalist development in China's post-reform era facilitates the development of a civil society (Chen, 2002; He, 1997; Huang, 1993; White, 1993, 1996). Moreover, the rapid development of communication and information technologies in the past two decades has made the Internet and social media widely available to ordinary Chinese citizens, fundamentally changing the ways of communication and bringing new elements to the development of a public sphere in China.

Prior studies have discussed the emergence, size and nature of the public sphere or civil society in China (Tang, 2007; Yang, 2003, 2007, 2009, 2010; Zheng, 2008), but few have examined the potential influence of social media on aspects of the Chinese civil society. To fill in this gap and as a first step, we examine the relationship of social media with two aspects of the public sphere in China: public discourse and civic engagement (Putnam, 1996; Yang, 2010). We also examine how individual characteristics, such as political interest, life satisfaction, and interpersonal trust might moderate the relationship between social media usage and citizens' participation in public discourse and civic activities due to the significance of the factors suggested in the literature.

\footnotetext{
${ }^{1}$ Public sphere here means everything that is outside of the domestic/familial sphere and the state/governmental sphere (Fraser 1990).
} 
Our paper is structured as below. First, we discuss the developmental stages of the Internet and social media in mainland China. We then theoretically explain how social media use could influence both public discourse and civic engagement in China. Next, we explore how the effect of social media on public discourse and civic engagement might differ among Chinese citizens dependent upon their individual characteristics such as their levels of political interest, life satisfaction and general trust in people.

\section{The Development of Internet and Social Media in China}

Since the Internet was first introduced to China in 1994, the number of Internet users has increased exponentially in the country. In 1997, China only had 1 million Internet users, but this number skyrocketed to 11 millions in 2005 and to 649 millions in 2014 (China Internet Network Information Center [CNNIC], 1998, 2008, 2015). During this time period, social media have gone through three developmental phases and have gradually become one of the most popular media types in China.

Before 2005 the bulletin board system (BBS) was the main form of social media. Popular BBS sites included online forums with major portal sites such as Sina.com, Sohu.com and 163.com, and more specialized bulletin board sites such as Tianya, Maopu, Qiangguoluntan (i.e., Strengthening the Nation Forum) and Xicihutong. Even today, BBS is still fairly popular among Chinese netizens. Between 2006 and 2008, multiple social media sites emerged where users can interact with friends and post pictures, status, and comments. Renren.com (a Chinese version of Facebook), for example, was one of the most widely used social media platforms during this phase. A chatting software QQ also became popular during this time. Since 2009, social media have entered the third phase whereby various social media applications were launched and quickly became popular 
among Chinese people, first Weibo (Chinese version of Twitter) in 2009, and then Weixin (an instant messaging social media platform) in 2011. Weixin has immediately attracted an unprecedentedly large amount of users and become the most popular social media tool in China, followed by QQ and Weibo (CNNIC, 2014). Today approximately 89\% of online Chinese use Weixin and other instant messaging apps, $61 \%$ use QQ, and 44\% use Weibo and other micro-blog sites (Kantar, 2015).

Social media have fundamentally changed the ways people entertain, shop and communicate with one another (CNNIC, 2014). Chinese use social media to obtain news, monitor friends' status, upload pictures, update their status, post their dairy, comments and share information, watch videos and listen to music. However, there are slight differences in the use of each type of social media. While Chinese netizens primarily use QQ and other social media sites to upload pictures, diary and to update their status, they use Weibo and other micro blogging sites to obtain news and monitor the status of people whom they are interested in. Weixin and other instant messaging apps are primarily used to chat with friends and monitor friends' status.

The majority of the Chinese Internet users are young, with 78\% younger than 39 years old. Most of them only have high school education or lower, and spend an average of 26 hours on the Internet in a typical week. ${ }^{2}$ In contrast, Chinese social media users are slightly more educated, with approximately half of them with an associate's degree or higher. They also tend to be younger, with nearly $65 \%$ of them below the age of 30 (CNNIC, 2015).

\section{Social Media and Public Discourse}

\footnotetext{
${ }^{2}$ According to the CNNIC (2015) report, about 37\% of online Chinese have middle school education and $31 \%$ have high school education or technical/vocational training, whereas those with an associate's degree or higher only comprise $22 \%$ of online Chinese.
} 
Social media help build a public sphere where people can exchange ideas freely through "meetings, debates, dialogues and discussions" (Cogburn \& Espinoza-Vasquez, 2011, p.194; Chadwick, 2008; Habermas, 1991). With social media, individual citizens can now easily access and gain information on various political and social issues and become more informed and rational (Dahlberg, 2001). In addition, social media and computer networking offer “cheap, decentralized, two-way communication” and enable people to participate virtually through email lists, electronic bulletin boards, online chat groups, and the like (Dahlberg, 2001, p. 164). Therefore, social media provide a unique virtual space for citizens to engage in free and open dialogues, whereby "participants put forward and challenge claims and arguments about common problems, not resting until satisfied that the best reasons have been given and fully defended. Participants attempt to come to an understanding of their interlocutors and to reflexively modify their prediscursive positions in response to better arguments” (Dahlberg, 2001, p. 165).

To use a popular Chinese BBS, Qiangguoluntan, as an example, we find that a variety of political topics were discussed in August 2015 alone. Subscribers of this BBS had heated discussions on issues such as corruption, the anti-corruption movement by President Xi Jinping, territorial disputes with Japan, pension system for migrant workers, health care reform, pollution and environmental protection, reform of state-owned enterprises, recent stock market crash, and law and constitutionalism in China. The discussions on this site are quite free and open. For instance, a discussion thread under the discussion panel of "Monitor by the People” called for ordinary Chinese citizens to use this panel to expose misconducts of government officials and monitor governmental 
activities. ${ }^{3}$ More than 200 people responded to the thread and debated on whether or not the panel can really influence politics. One user complained about the deletion of her post on some governmental officials' misconduct, and another user argued that without a true democratic political system, “monitor by the people” will only be an empty dream. Such a public sphere where citizens can openly discuss or debate on political issues was nearly nonexistent in Chinese history, and perhaps the “big-character posters” in Mao’s era were the only exception (Yang, 2010, p. 463).

While the Chinese government strictly monitors the content in mass media such as newspapers, TV and even the Internet, social media is perhaps the medium where censorship is most difficult to carry out. When a political commentary is posted on Weibo for instance, thousands of Weibo users can instantly access this post and share this post to their friends/followers. Posts can be also shared and re-shared through Weixin instantly and reach a large volume of audience within seconds. The rapid diffusion of information and difficulty of censorship makes social media a unique platform for ordinary Chinese citizens to articulate their own problems and voice their opinions (Yang, 2010). For example, a woman posted a message in friend circles on Weixin and complained about local government confiscating her houses while developing an industrial park without offering enough compensation. The message was first posted in the woman’s QQ space and was then quickly and widely spread through friends’ circles on Weixin.

\footnotetext{
${ }^{3}$ In a thread titled "Let us develop supervising and monitoring government behavior as a daily habit," the creator of the panel maintains that this panel will enable ordinary Chinese people to monitor governmental actions by revealing misconduct of government officials; therefore they called for Chinese citizens to turn "supervising and monitoring government behavior as a daily habit." To read the post, see http://bbs1.people.com.cn/post/71/1/2/93823058.html
} 
Based on the theorization of cyberspace's role in public discourse and the two examples, we postulate that individuals who use social media more often will be more exposed to various political information and discussions online, and therefore more likely to engage in these public debates and political discussions online. We argue that the positive effect of social media can extend to offline space and promote general public discourse. Particularly, once individuals actively use social media to engage in online discussions on certain issues, they will naturally bring the discussions to their circles of friends, coworkers, classmates and acquaintances and further discuss or debate on these issues with them. Therefore, social media usage should be positively related to both online public discourse and public discourse in general. The first hypothesis is below:

H1: Individuals who use social media more often will be more likely to engage in online public discourse and public discourse in general.

\section{Social Media and Civic Engagement}

Not only do social media promote public discourse, they can also potentially involve individuals in civic activities. Civic engagement is referred to as individuals’ connections with their communities and includes any political or non-political activities that enhance the quality of life in a community (Ehrlich, 2012; see also Obar, Zube \& Lampe, 2012; Putnam, 1996).

The role of information and communication technologies in civic engagement is somewhat controversial. Putnam (1996) posits that television watching is responsible for the declining civic engagement in the United States. The Internet is also suspected to disengage people from civic matters for three reasons (Kraut, Patterson, Lundmark, Kiesler, Mukopadhyay \& Scherlis, 1998; Putnam, 2000). First, it is likely that when 
people use most of their online time on shopping and entertainment, they are likely to be less involved in civic matters (Camaerts, 2008). Second, surveillance and censorship by states and employers could discourage citizens from participating in public affairs (Cammaerts, 2008; Krueger, 2005). Finally, online communication (e.g., electronic conversations, bulletin boards, chat rooms, and virtual conferences) is only a poor substitute for traditional face-to-face interaction, and therefore does not contribute to healthy civic engagement (Jennings \& Zeitner, 2003; see also Kraut et al., 1998; Putnam, 2000). Yet, contrary to the conventional prediction that the Internet disengages civic participation, numerous studies find that the Internet, especially social media, promotes civic engagement. Online communication may be used to support offline relationships and keep people connected despite of geographical boundaries (Helliwell \& Putnam, 2004; see also Cogburn \& Espinoza-Vasquez, 2011). Internet usage is also shown to have a positive effect on volunteering for charities (de Zúñiga, Jung \& Valenzuela, 2012).

The positive relationship between social media and civic engagement perhaps resides in the mechanism of social capital. Social capital is "the aggregate of the actual or potential resources which are linked to possession of a durable network of more or less institutionalized relationships of mutual acquaintance or recognition” (Bourdieu, 1985, p.248; see also Portes, 2000). When individuals participate virtually through electronic bulletin boards, online chat groups, and the like, they become bound by shared problems, interests, ideologies and values and form a sense of belonging (Watson, 1997; Wellman \& Gulia, 1999). These social media platforms bring total strangers together and maintain interpersonal ties relatively easily and inexpensively (Davis, Baumgartner, Francia \& Morris, 2008). As a result, virtual communities are formed to provide informal 
associational spaces, and play an important role in replacing the degraded pubic sphere of modern urban life (Heim, 1991; Stone, 1991). Studies show that social media such as Facebook and Twitter promote civic engagement (Backhouse \& Canberra, 2008; Donath \& Boyd, 2004; Ellison, Steinfield \& Lampe, 2007). With social media, activities and events that were only available in a particular place can now be carried out anywhere (Van Dijk, 2006).

Examples of social media facilitating social activities and maintaining social ties can be easily found in today’s China. In an article titled “Cannot Say No to Class Reunions” published on People's Daily, Wang (2014) recounted that in the past he and his classmates were only able to have an offline classmate reunion every year or every few years. Typically, someone had to make phone calls to everybody to extend the invitation and eventually confirm attendance, which was a big hassle and not effective. However, nowadays, because of the group chats function in Weixin, they can have a class reunion carnival nearly everyday. According to Wang, with Weixin, now anyone can "throw" a suggestion for reunion in the group chat, which normally will result in a heated discussion and a gathering together somewhere.

Another interesting example is the square dance groups in China. In almost every city, women and men get together to dance in public squares. In Shenhe Distrct of Shenyang City, the square dance group led by Ms. Wu Ying started using Weixin to spread the word about their dancing group when it was first established in May 2014 (Li \& Bao, 2015). Soon, their dancing group expanded from about 10 people to almost 60 people. They then used Weixin group chats to share information on group activities, competitions with other groups, as well as dancing videos. Wu indicated that Weixin 
made their communication much more effective and they were able to connect with group members easily (Li \& Bao, 2015).

Social media also make engagement in charitable and volunteering activities much easier than before. On May 2, 2015, the Women and Children’s Hospital in Yueqing City in Zhejiang province charged a 26-week pregnant woman, Ms. Chen, experiencing hemorrhage due to placenta previa (Liu, 2015). The hospital used up all AB type blood and needed more. Right after the surgery, a staff in the hospital posted a message in the Weixin group soliciting blood donation at about 4pm on May 3, which was immediately shared by doctors, nurses and staff members into their own friend circles. Within hours, more than 20 volunteers came to the hospital to donate blood. By 8pm on the same day, the hospital collected 3100 CC AB type blood and saved Ms. Chen’s life (Liu, 2015).

These three examples vividly demonstrate the effectiveness of social media in engaging citizens in civic activities such as networking group events, interest-based group activities, as well as charitable and voluntary activities. Therefore, we develop our second hypothesis as below:

H2: Individuals with more social media usage will be more likely to engage in civic activities.

\section{Who's Likely to Use Social Media for Civic Purposes?}

Although social media could potentially bolster civic engagement and public discourse, social media usage itself does not automatically translate into a higher level of civic participation (Gustafsson, 2012). People who use social media primarily for entertainment and personal social network might not necessarily use it for communal and 
civic purposes. Members of interest organizations take advantage of social networking sites to actively participate in public and political matters; however, their counterparts prefer, in general, to remain passive despite of being exposed to political content and requests for participation (Gustafsson, 2012). The Internet's potential for civic engagement is stronger for people with more interests in public affairs or those who are already politically engaged (Bimber, 2003; Xenos \& Moy, 2007). In other words, social media use may prompt individuals with higher levels of political interest to engage in public discourse and civic activities, but may not automatically make politically apathetic individuals participate in various public and civic affairs.

Besides political interest, general trust in others may play a pivotal role in public discourse and civic engagement. Trusting individuals are also less concerned about being taken advantage of by other people, civic organizations or the government (Brehm \& Rahn 1997; Chen \& Lu, 2007). Therefore, trusting individuals are more likely to take part in various civic activities. Prior research finds that trust can predict giving and volunteering (Taniguchi \& Marshall, 2014). Often interpreted as an important component of social capital, interpersonal trust is deemed to promote cooperation among citizens and make public and political institutions function smoothly (Putnam, Leonardi, \& Nanetti, 1993; see also Yang \& Tang, 2010). Therefore, for highly trusting individuals, a little exposure to social media may go a long way; in other words, it is much more likely for trusting individuals to utilize social media platforms to engage in various civic activities such as public discourse and associational life. Yet, for cynical or less trusting individuals, exposure to social media might not necessarily motivate them to engage in civic activities. 
Valenzuela, Park, and Kee (2009) reported that the correlation of using the social network site with college students' political engagement was stronger for trusting individuals than for the counterparts.

The role of social media use in public discourse and civic engagement should also be contingent on life satisfaction. Life satisfaction refers to a positive or negative evaluation of one's life conditions and quality (Diener, Lucas, \& Oishi, 2002), and is in part a result of social relations (Kahneman \& Krueger, 2006). Previous studies have reported that life contentment is related to favorable attitudes towards mass participation and democratic government (Inglehart, 1997; Sullivan \& Transue, 1999), joint actions (Fuller \& Hester, 1998; Harlow \& Cantor, 1996), and engagement in community events (Scheufele, 1999). Additionally, to feel good about one's self, people often participate in volunteering and other helping behaviors (Omoto \& Snyder, 1995). Therefore, we postulate that for individuals who are more content with their lives, social media use is more likely to prompt them to reach out, voice their opinions, and engage in civic activities, whereas for individuals with a lower level of life satisfaction, the links between social media use and engagement in public discourse and civic activities are weaker. However, Valenzuela, Park, and Kee (2009) did not find an interaction effect between life satisfaction and social networking site use on political participation among college students. Our study will test this interaction effect on public discourse and civic engagement among Chinese adults.

Based on these contentions, we propose the following hypotheses testing the moderating effect of political interest, generalized trust, and life satisfaction on the relationship between social media use and public discourse and civic engagement: 
H1-a, b, and c: Individuals with higher levels of political interest, generalized trust and life satisfaction are more likely to use social media to engage in public discourse.

H2-a, b, and c: Individuals with higher levels of political interest, generalized trust and life satisfaction are more likely to use social media to engage in civic activities.

\section{Methods}

\section{Sample}

We utilize originally collected survey data to test our hypotheses. The survey was conducted in November 2013 by a market research company that has a database covering more than 400,000 users from more than 31 provinces and districts of China. A random sample of 17,035 Internet users was invited to participate in the study, and 1,202 returned questionnaires were valid (response rate $=7.06 \%$ ). The sample was weighted by gender to make it more representative of the population of Chinese Internet users. According to a report by the China Internet Network and Information Center (2014), by December of 2013, 56\% of Chinese Internet users were male. The weighted Chinese sample had 55.6\% males.

\section{Measures}

Public discourse. We use two indicators to measure public discourse: online public discourse and general public discourse. We measure participation in online public discourse by asking participants to rate how often they engage in online conversations about public affairs, policies, and public officials through Weibo, QQ group or QQ/MSN, and forum/BBS/blog on a 7-point Likert-type scale $(1=$ not at all and $7=a$ lot $)$. The 
scale had a Cronbach's $\alpha$ of $.90 ; M=4.04(S D=1.51)$. General public discourse was measured on a 7-point Likert-type scale $(1=$ not at all and $7=a$ lot $)$. Participants rated how often they discuss with colleagues/classmates and friends about public affairs, policies, and government officials. The scale’s reliability was .69, and the mean was 4.29 $(S D=1.16)$.

Civic engagement. Discussions of civic engagement in the U.S. often focus on voluntary groups and programs and prior research uses volunteering for charities as a measure for civic engagement in research (Putnam 1996, 2000; de Zuniga et al., 2012). Following this tradition, we use a series of voluntary activities to measure Chinese citizens' level of civic engagement. Participants were asked to rate on a 7-point Likerttype scale $(1=$ not at all and $7=a$ lot $)$ how often they engaged in the following activities: participate in various kinds of social events organized by communities; volunteer; participate in protests or events related to environment protection; and engage in various kinds of donations (e.g., blood donation, monetary and goods donation). The scale had a high level of reliability (Cronbach's $\alpha=.92)$; and $M=3.72(S D=1.39)$.

Social media use. Participants were asked if they had used any of the four social media platforms, including BBS, blogs, Weibo (i.e., Microblog), and Weixin. For each of the four social media platforms, participants were categorized into one of the three usage groups: non-users, non-frequent users, and frequent users. Participants who had not used it in the past six months were categorized as "non-users" (coded as 0); participants who had used it in the past six months but sometimes discontinued for more than one week were categorized as "non-frequent users" (coded as 1); and people who had continuously 
used it in the past six months were categorized as "frequent user" (coded as 2). Thus, the value of social media use can range from 0 to 8 .

A principle component factor analysis with Varimax rotation yielded a factor (Eigenvalue $=2.28$ ) with factor loadings ranging from .70 to .80 , which explained $57 \%$ of the variance. The scale had a Cronbach's $\alpha$ of.75. We summed the four items for each participant $(M=4.95$ and $S D=2.35)$, and Table 1 reports the makeup of users within each social media platform.

Political interest. Participants rated their political interests on a 7-point Likert scale (1= strongly disagree, 7 = strongly agree) (Cronbach's $\alpha=.89)$ for the following statements: "I am interested in political or public affairs," "I search for information on public affairs or politics,” and “It is worthy of spending time thinking of politics or public affairs.” The items were summed and averaged for each participant, $M=4.88$ (SD = 1.16).

Generalized trust. Participants were asked to rate how much they agree with the statement of “most people in society are trustworthy" on a Likert scale ( 1 = strongly disagree and $7=$ strongly agree $)$. The mean of this measure was $4.48(S D=1.42)$.

Life satisfaction. Participants were asked to rate how much they agree with the following statements on a Likert scale (1 = strongly disagree and 7 = strongly agree): "My life is close to my expectations on many aspects," "My life is very good on every aspect,” and “I am satisfied with my life.” The scale was highly reliable (Cronbach's $\alpha=$ $.92)$. The mean was $4.17(S D=1.37)$.

We also included a full set of control variables, including participants' use of traditional media and their demographics. 
Traditional media use. Participants were asked to indicate how many minutes on an average day they spent reading newspapers, watching TV, and surfing on the Web. We transformed all the values by adding one to the original value and then taking the logarithm of the sum, so the distributions are closer to a normal distribution. The results were $2.50(S D=1.82)$ for reading newspapers, $3.15(S D=.91)$ for watching $\mathrm{TV}$, and $5.25(S D=.82)$ for surfing online.

Demographics. We measured participants' demographics, including age, gender, education, monthly family household income, and employment status. The average age was 32.87 years old $(S D=8.30)$. Education was measured on a 4-point scale $(1=$ high school or below; $4=$ post graduate degree $)$, and the mean was $2.67(S D=.75)$. Family household income was measured on a 12-point scale ( 1 = RMB¥1000 [ $\$ 161$ or so] or less; $12=\mathrm{RMB} ¥ 30,000[\$ 4,838]$ and above $)$, and the mean was $6.67(S D=2.56)$. Approximately 84\% of the participants had a full-time job.

\section{Analytical Methods}

To test whether or not there is a relationship between social media use and each dependent variable (i.e., online public discourse, general public discourse, and civic engagement), we performed a series of multiple linear regression analyses. Each analysis regresses the dependent variable on the confounding variables and social media use. Then, to test the modification of each of the three variables (i.e., political interest, generalized trust and life satisfaction), we regressed each dependent variable on social media use, the moderating factor of interest, the interaction between social media use and the respective moderating factor, as well as the confounding variables. Social media use and the three conditioning variables were centered at their means for the analyses. 


\section{Results}

\section{Social Media Use and Public Discourse}

Our hypothesis 1 posits that social media use should be positively related to engagement in public discourse, and our results confirm this hypothesis after controlling for age, gender, income, education, employment status, and use of various traditional media. In Table 2, when we use online public discourse as the dependent variable, social media has a $t(1192)=10.75, p<.001$ (unstandardized $\beta=.18, S E=.02$ ). Therefore, more frequent social media use is linked to a higher level of engagement in online public discourse. When we use the general public discourse as the dependent variable, we find the same positive association: $t(1192)=5.66, p<.001$ (unstandardized $\beta=.08, S E=$ .01). More frequent social media use is associated with a higher level of engagement in general public discourse as well.

Hypothesis 1a predicts an interaction effect between social media use and political interest on engagement in public discourse. Our results confirm this hypothesis (see Table 3). Regarding online public discourse, the coefficient of the interaction term between social media and political interest is positive and significant, $t(1190)=3.41, p=$ .001 (unstandardized $\beta=.04, S E=.01$ ). The interaction of political interest and social media use is also significant for general public discourse given that $t(1190)=3.13, p<$ .01 , unstandardized $\beta=.03, S E=.01$. Both results suggest that the positive correlation of social media with public discourse is strengthened among individuals with higher levels of political interest.

Hypothesis 1b posits a conditional effect of general trust on the relationship between social media use and public discourse. This hypothesis is only partially 
supported. When we use online public discourse as our dependent variable as shown in Table 4, the interaction was not significant with a $t(1190)=.36, p>.05$ (unstandardized $\beta=.004, S E=.01)$. Yet, when we use general public discourse as the dependent variable, the interaction of social media use with general trust in people was indeed significant, with a $t(1190)=2.12, p<.05$, unstandardized $\beta=.02, S E=.01$. These results suggest that as the level of trusting increases, social media use's positive association with general public discourse strengthens. Yet this conditional effect is not found in online public discourse.

Hypothesis 1c predicts a conditional effect of life satisfaction on the relationship between social media and public discourse, and this hypothesis also only finds support when we use general public discourse as the measure of our dependent variable (Table 5). While the interaction between life satisfaction and social media use does not have a significant effect on online public discourse as shown in Table $5(t=.19, p>.05$; unstandardized $\beta=.002, S E=.01$ ), it does have a significant effect on general public discourse: $t(1190)=2.38, p<.05$, unstandardized $\beta=.02, S E=.01$.

To sum up, we find consistent evidence that more frequent social media use is associated with higher levels of public discourse regardless of the space where public discourse takes place. Individuals who use social media more frequently are more likely to engage in both online public discourse and public discourse in general. We also find consistent evidence that political interest conditions the effect of social media and public discourse. However, we only find partial evidence for the conditional effects of generalized trust in people and life satisfaction on the relationship between social media and public discourse. 


\section{Social Media Use and Civic Engagement}

Our hypothesis 2 predicts a positive relationship between social media use and civic engagement, and results show strong support to this hypothesis (see Table 2). Social media use is positively related to civic engagement, $t(1192)=5.64, p<.001$, unstandardized $\beta=.09, S E=.02$. The more frequently a respondent uses social media, the more an individual engages in civic activities such as volunteering and charitable donations.

Hypotheses 2a, 2b, and 2c propose that the link between social media use and civic engagement is contingent on political interest, general trust, and life satisfaction, respectively. Results confirm hypothesis $2 \mathrm{a}$ in that the interaction term between social media use and political interest has a significant effect, as shown in Table $3(t(1190)=$ 2.62, $p<.01$, unstandardized $\beta=.03, S E=.01$ ). Hypothesis $2 \mathrm{c}$ is also supported given that the interaction term between life satisfaction and social media use has a significant effect as shown in Table $5(t(1190)=2.07, p<.05$, unstandardized $\beta=.02$, SE $=.01)$. These results suggest that both political interest and life satisfaction modify the relationship between social media use and civic engagement. The interaction between social media use and general trust in people, however, does not have a significant effect on civic engagement as shown in Table $4(t(1190)=1.26, p>.05$, unstandardized $\beta=$ $.01, S E=.01)$. Thus, hypothesis $2 \mathrm{~b}$ was not supported.

In sum, we find consistent support for a positive relationship between social media use and civic engagement. In China, more frequent usage of social media is linked to higher levels of civic engagement. This relationship is found to be conditional upon both political interest and life satisfaction. Individuals with higher levels of political 
interest and higher levels of life satisfaction are more likely to utilize social media to participate in civic activates.

\section{Discussion}

Social media use has become a popular phenomenon in mainland China as more than half of online Chinese use at least some types of social media (CNNIC, 2014). Surprisingly, few prior studies have examined the influence of social media on the development of a public sphere in China. Although many western scholars have doubted the existence of an independent civil society in China, a handful of qualitative studies presented promising anecdotes on how Internet has facilitated the development of China’s civil society (Yang, 2003, 2007, 2010). Different from previous studies, we differentiate social media from the Internet and examine the effect of social media on the development of the Chinese civil society. By using originally collected survey data, our paper offers the first scientific and quantitative empirical test on the relation of social media use with two important aspects of the civil society—-public discourse and civic engagement.

The most salient and interesting finding is that in China, individuals with more frequent social media use are indeed more likely to engage in both public discourse and civic activities. These findings echo a positive linkage between social media and civic engagement that was long documented in the Western settings (Valenzuela, Park \& Kee, 2009). Our paper shows that social media have a similar effect on civic participation in an authoritarian political system where censorship is existent. Moreover, our findings extend the theorization about the Internet's positive role in public discourse and civic engagement to the context of social media (Dahlberg, 2001; Yang 2003, 2007, 2010). 
Dahlberg (2001) argues that cyberspace has the potentials to facilitate democracy, for three reasons. First of all, with the Internet and social media, individual citizens can now easily access and gain information on various political and social issues, and become more informed citizens and make rational political choices. Second, the Internet and computer networking enables people to form virtual communities (Dahlberg, 2001). Finally, the Internet, especially the interactive social media, has the potential to involve citizens in free and open public discourse in a democratic cyberspace. Therefore, through these three mechanisms - the individualistic, the communitarian and the deliberative democracy models_cyber-democracy could become a reality. Our study shows support to at least two of the three mechanisms: the communitarian and the deliberative democracy models. We find that social media facilitate the development of a communitarian and deliberative cyberspace through promoting deliberative public discourse and communitarian civic engagement. We believe these potentials of social media will eventually facilitate the democratic development of China.

Bach and Stark (2004) posit that the interactive, multiplicative information technology facilitates the forming of new social bonds and new organizations and increases participation and impact due to low transaction costs and streamlined operations. In a similar vein, our study show that social media have the potential to foster a public sphere for free and open discussions and to form and strengthen community senses, and have created new possibilities for China's political future.

Interestingly, we find that the relationship between social media and public discourse and civic engagement is conditioned by individual characteristics such as political interest, generalized trust and life satisfaction. Generally speaking, individuals 
with higher levels of political interest and higher levels of life satisfaction are more likely to utilize social media to engage in public discourse and civic activities. Previous studies have reported that people who are politically engaged are more likely to use the Internet for political engagement (Bimber, 2003; Xenos \& Moy, 2007), and we find that social media's potential for public discourse and civic engagement is stronger for people with more political interest. These results demonstrate that political interest is a pivotal factor of active participation in public affairs and civic activities, even though advances in communication and information technologies have make civic engagement much easier than before.

We also find that social media's effect on civic engagement is dependent on life satisfaction but not on generalized trust in people. The finding of a strong intertwine among social media use, life satisfaction and civic engagement is contradictory to Valenzuela et al.’s (2009) study which did not find a significant interaction effect between life satisfaction and Facebook use intensity on political participation among college students. We suspect that the interaction effect is present among Chinese citizens for several reasons. First of all, previous research has shown that social media use increases and strengthens social ties and social capital (Davis et al., 2008; Ellison et al., 2007; Watson, 1997; Wellman \& Gulia, 1999), and a feeling of connectedness with others is important for life satisfaction. Subsequently, people with a high level of life satisfaction are more likely to engage in civic events (Fuller \& Hester, 1998; Harlow \& Cantor, 1996; Inglehart, 1997; Scheufele, 1999; Sullivan \& Transue, 1999). Second, the interaction effect emerges perhaps due to our measure of the use of a wide range of social media, including BBS, blogs, and Weibo (i.e., Microblog), whereas Valenzuela et al. 
(2009) measured the use of Facebook only. Finally, the significant interaction effect is possibly due to the recent development of the Chinese civil society. It is known that an independent civil society was nearly non-existent during the Maoist era (Jennings, 1997; Yang, 2007). With the rapid and constant changes and development of communication technologies, there has been an unprecedented engagement in public discourse and civic activities among Chinese citizens and the moderation effect of life satisfaction can therefore be observed.

\section{Limitations and Future Research}

Despite its significant contributions to the understanding of social media use's role in public discourse and civic engagement, the current study is not without limitations. The study relies on survey data and cannot test causations among the variables of interest. The measurements are based on self-reported responses, and may be biased. Additionally, we examine civic engagement by focusing on volunteering and voluntary donations, but civic engagement encompasses both non-political and political activities that aim to improve community life quality and therefore could cover a wide range of activities. Therefore, future research is needed to investigate more comprehensively how social media use is related to both political and non-political engagement in China. Further, the current study focuses on moderating factors, including political interest, general trust, and life satisfaction; future studies can advance the field by testing mediating factors between social media use and public discourse and civic engagement. 


\section{References}

Backhouse, J., \& Canberra, A. (2008). Election campaigning in the era of web 2.0 and social media. Paper presented at the International Conference on E-Government, Melbourne, Australia.

Barker, C., \& Martin, B. (2011). Participation: The happiness in connection. Journal of Public Deliberation, 7, Article 9. Retrieved from http://www.publicdeliberation.net/cgi/viewcontent.cgi?article=1167\&context=jpd.

Boudieu, P. (1986). The forms of capital. In J. Richardson (Ed.), Handbook of theory and research for the sociology of education pp. 241-258). New York: Greenwood Press.

Cammaerts, B. (2008). Critiques on the participatory potentials of web 2.0. Communication, Culture \& Critique, 1, 358-377.

Carroll, W. K., \& Hackett, R. A. (2006). Democratic media activism through the lens of social movement theory. Media, Culture \& Society, 28, 83-104.

Chadwick, A. (2008). Web 2.0: New challenges for the study of e-democracy in an era of informational exuberance. Journal of Law and Policy for the Information Society, 5, 9-41.

Chen, A. (2002). Capitalist development, entrepreneurial class, and democratization in china. Political Science Quarterly, 117, 401-422.

China Internet Network and Information Center (1998). The 2nd report of the development of the Internet in China. Retrieved from http://www.cnnic.cn/hlwfzyj/hlwxzbg/200905/P020120709345373784718.pdf 
China Internet Network and Information Center (July 2008). The 22nd report of the development of the Internet in China. Retrieved from http://www.cnnic.cn/hlwfzyj/hlwxzbg/index_3.htm

China Internet Network and Information Center (July 2014). 2014 research report of the behaviors of social media users in China. Retrieved from http://www.cnnic.cn/hlwfzyj/hlwxzbg/201408/P020140822379356612744.pdf

China Internet Network and Information Center (January 2015). The 35th report of the development of the Internet in China. Retrieved from http://www.cnnic.cn/hlwfzyj/hlwxzbg/201502/P020150203551802054676.pdf

Cogburn, D. L., \& Espinoza-Vasquezb, F. K. (2011). From networked nominee to networked nation: Examining the impact of web 2.0 and social media on political participation and civic engagement in the 2008 obama campaign. Journal of Political Marketing, 10, 189-213.

Dahlberg, L. (2001). Democracy via cyberspace-mapping the rhetorics and practices of three prominent camps. New Media and Society, 3, 157-177.

Davis, R., Baumgartner, J. C., Francia, P. L., \& Morris, J. S. (2008). The Internet in U.S. election campaigns. In A. Chadwick (Ed.), Routledge handbook of internet politics (pp. 241-244). New York: Taylor \& Francis.

de Zúñiga, H. G., Jung, N., \& Valenzuela, S. (2012). Social media use for news and individuals' social capital, civic engagement and political participation. Journal of Computer-Mediated Communication, 17, 319-336. 
Diener, E., Lucas, R. E., \& Oishi, S. (2002). Subjective well-being: The science of happiness and life satisfaction. In C. R. Snyder \& S. J. Lopez (Eds.), Handbook of positive psychology (pp. 63-73). New York: Oxford University Press.

Dijk, J. V. (2006). The network society: Social aspects of new media. Thousand Oaks, CA: Sage.

Donath, J., \& Boyd, D. (2004). Public displays of connection. BT Technology Journal, 22, 71-82.

Ehrlich, T. (2000). Civic responsibility and higher education. Westport, CT: Oryx Press.

Ellison, N. B., Steinfield, C., \& Lampe, C. (2007). The benefits of Facebook "friends": Social capital and college students' use of online social network sites. Journal of Computer-Mediated Communication, 12, 1143.

Ferber, P., Foltz, F. \& Pugliese, R. (2007). Cyberdemocracy and online politics: A new model of interactivity. Bulletin of Science, Technology \& Society, 27, 391-400.

Fraser, N. (1990). Rethinking the public sphere: A contribution to the critique of actually existing democracy. Social Text, 25/26, 56-80.

Fuller, J. B., \& Hester, K. (1998). The effect of labor relations climate on the union participation process. Journal of Labor Research, 19, 173-188.

Green, L. (2002). Communication, technology and society. London: Sage.

Habermas, J. (1991). The structural transformation of the public sphere: An inquiry into a category of bourgeois society. Cambridge, MA: MIT Press.

Harlow, R. E., \& Cantor, N. (1996). Still participating after all these years: A study of life task participation in later life. Journal of Personality and Social Psychology, 71, 1235-1250. 
He, B. (1996). The democratization of china. London and New York: Routledge.

He, B. (1997). The democratic implications of civil society in china. Basingstoke, UK: Macmillan Press.

Helliwell, J. F., \& Putnam, R. D. (2004). The social context of well-being. Philosophical Transactions: Biological Sciences, 359, 1435-1446.

Huang, P. C. C. (1993). "Public sphere" or "civil society" in china? The third realm between state and society. Modern China, 19, 216-240.

Inglehart, R. (1997). Modernization and postmodernization: Cultural, economic, and political change in 43 countries. Princeton, NJ: Princeton University Press.

Jennings, M. K. (1997). Political participation in the chinese countryside. The American Political Science Review, 91, 361-372.

Jennings, M. K., \& Zeitner, V. (2003). Internet use and civic engagement. Public Opinion Quarterly, 67, 311-334.

Kantar (2015). 2015 annual report on effects of Chinese social media. Retrieved from http://cn.kantar.com/media/909009/2015____pdf

Kraut, R. E., Patterson, M., Lundmark, V., Kiesler, S., Mukopadhyay, T., \& Scherlis, W. (1998). Internet paradox: A social technology that reduces social involvement and psychological well-being? American Psychologist, 53, 1017-1031.

Krueger, B. S. (2005). Government surveillance and political participation on the internet. Social Science Computer Review, 23, 439-452.

Li, G., \& Bao, J. (2015, May 23, 2015). Weixin group chats became new learning platform for square dance women, Huashang Morning Newspaper. Retrieved from http://e.hsxiang.com/html/2015-05/23/content_497065.htm 
Liu, L. (May 6, 2015). Friends' circle spreads information, Weixin group shows lovesocial media users donate blood to save pregnant woman, Leqing Daily. Retrieved from http://news.163.com/15/0506/00/AOT1A2Q700014AED.html

Obar, J. A., Zube, P., \& Lampe, C. (2012). Advocacy 2.0: An analysis of how advocacy groups in the united states perceive and use social media as tools for facilitating civic engagement and collective action. Journal of Information Policy, 2, 1-25.

Omoto, A. M., \& Snyder, M (1995). Sustained helping without obligation: Motivation, longevity of service, and perceived attitude change among AIDS volunteers. Journal of Personality and Social Psychology, 68, 671-686.

Portes, A. (2000). Social capital: Its origins and applications in modern sociology. In E. Lesser (Ed.), Knowledge and social capital (pp. 43-67). Boston: ButterworthHeinemann.

Putnam, R. (2000). Bowling alone: The collapse and revival of american community. New York: Simon \& Schuster.

Putnam, R. D. (1996). The strange disappearance of civic america. The American Prospect, 24, 34-48.

Putnam, R. D., Leonardi, R., \& Nanetti, R. Y. (1993). Making democracy work. Princeton, NJ: Princeton University Press.

Valenzuela, S., Park, N., \& Kee, K. F. (2009). Is there social capital in a social network site? Facebook use and college students’ life satisfaction, trust, and participation. Journal of Computer-Mediated Communication, 14, 875-901. 
Sullivan, J. L., \& Transue, J. E. (1999). The psychological underpinnings of democracy: A selective review of research on political tolerance, interpersonal trust, and social capital. Annual Review of Psychology, 50, 625-650.

Taniguchi, H., \& Marshall, G. A. (2014). The effects of social trust and institutional trust on formal volunteering and charitable giving in Japan. Voluntas, 25, 150-175.

Teng, X., \& Yang, B. (2009). Does internet eliminate gender gap in civic engagement? An exploration of the two bbs "tianya tittle-tattle" and "maoyankanren". Chinese Journal of Computer-Mediated Communication, 3, 185.

van Ingen, E., \& Bekkers, R. (2015). Generalized trust through civic engagement? Evidence from five national panel studies.

Valenzuela, S., Park, N., \& Kee, K. F. (2009). Is there social capital in a social network site? Facebook use and college students' life satisfaction, trust, and participation. Journal of Computer-Mediated Communication, 14, 875-901. DOI:

10.1111/j.1083-6101.2009.01474.x

Wang, H. (November 14, 2014). Can not say no to classmates reunion. People's Daily Overseas Edition. Retrieved from http://paper.people.com.cn/rmrbhwb/html/2014-11/14/content_1498651.htm

White, G. (1993). Prospects for civil society in china: A case study of xiaoshan city. The Australian Journal of Chinese Affairs, 29, 63-87.

White, G. (1996). Chinese trade unions in the transition from socialism: Towards corporatism or civil society? British Journal of Industrial Relations, 34, 433-457.

Yang, G. (2003). The co-evolution of the internet and civil society in china. Asian Survey, 43, 405-422. 
Yang, G. (2007). How do chinese civic associations respond to the internet? Findings from a survey. The China Quarterly, 189, 122-143.

Yang, G. (2009). The power of the internet in china: Citizen activism online. New York: Columbia University Press.

Yang, G. (2010). The internet and civil society in china: A preliminary assessment. Journal of Contemporary China, 12, 453-475.

Yang, Q., \& Tang, W. (2010). Exploring the sources of institutional trust in china:culture, mobilization, or performance? Asian Politics and Policy, 2, 415-336. 
Table 1

Distribution of Each Group of Users for Four Social Media Platforms

\begin{tabular}{ccccc}
\hline \multirow{2}{*}{ User Group } & \multicolumn{5}{c}{ Social Media Platform } \\
\cline { 2 - 5 } & BBS & Blog & Weibo & Weixin \\
& $(\mathrm{n})$ & $(\mathrm{n})$ & $(\mathrm{n})$ & $(\mathrm{n})$ \\
\hline Non-user & $30.0 \%$ & $31.3 \%$ & $14.3 \%$ & $19.0 \%$ \\
& $(361)$ & $(376)$ & $(172)$ & $(228)$ \\
\hline Non-frequent user & $35.3 \%$ & $36.1 \%$ & $25.0 \%$ & $19.1 \%$ \\
& $(425)$ & $(434)$ & $(300)$ & $(229)$ \\
\hline Frequent user & $34.6 \%$ & $32.6 \%$ & $60.7 \%$ & $(745)$ \\
\hline
\end{tabular}


Table 2

Results of Multiple Linear Regression Analyses on the Role of Social Media Use in Public Discourse and Civic Engagement

\section{Dependent Variable}

Online Public $\quad$ General public discourse $\quad$ Civic engagement

Explanatory Variable Discourse

\begin{tabular}{|c|c|c|c|c|c|c|}
\hline & $\mathrm{B}(S E)$ & $t$ & $\mathrm{~B}(S E)$ & $t$ & $\mathrm{~B}(S E)$ & $t$ \\
\hline Gender (female $=0$ ) & $.01(.08)$ & .18 & $.04(.06)$ & .72 & $-.06(.07)$ & -.89 \\
\hline Age & $-.02(.01)$ & $-3.19 * *$ & $.00(.00)$ & 1.16 & $-.01(.00)$ & -1.27 \\
\hline Education & $-.02(.05)$ & -.36 & $.07(.04)$ & 1.61 & $.15(.05)$ & $3.03 * *$ \\
\hline Family Income & $.13(.02)$ & $7.72 * * *$ & $.08(.01)$ & $5.66^{* * *}$ & $.09(.02)$ & $5.72 * * *$ \\
\hline Employment (no job = 0) & $.04(.10)$ & .36 & $.05(.08)$ & .54 & $-.03(.10)$ & -.32 \\
\hline Ln(ReadingNewspaper+1) & $.31(.04)$ & $7.76^{* * *}$ & $.22(.03)$ & $6.67 * * *$ & $.39(.04)$ & $10.39 * * *$ \\
\hline Ln (WatchingTv+1) & $.16(.05)$ & $3.46 * *$ & $.16(.04)$ & $4.24 * * *$ & $.14(.04)$ & $3.21 * *$ \\
\hline Ln (SurfingontheWeb+1) & $-.12(.05)$ & $-2.67 * *$ & $-.09(.04)$ & $-2.42^{*}$ & $-.29(.04)$ & $-6.65 * * *$ \\
\hline Social media use & $.18(.02)$ & $10.75^{* * *}$ & $.08(.01)$ & $5.66 * * *$ & $.09(.02)$ & $5.64 * * *$ \\
\hline
\end{tabular}

Note. ${ }^{*} p<.05 ; * * p<.01 ; * * * p<.001$ 
Table 3

Results of Multiple Linear Regression Analyses on Social Media Use and Political

Interest

\section{Dependent Variable}

Explanatory Variable

Online Public Discourse $\quad$ General Public Civic Engagement

Discourse

\begin{tabular}{|c|c|c|c|c|c|c|}
\hline & $\mathrm{B}(S E)$ & $t$ & $\mathrm{~B}(S E)$ & $t$ & $\mathrm{~B}(S E)$ & $t$ \\
\hline Gender & $-.07(.07)$ & -1.00 & $-.02(.05)$ & -.42 & $-.14(.06)$ & $-2.25^{*}$ \\
\hline Age & $-.02(.00)$ & $-5.10 * * *$ & $.00(.00)$ & -.16 & $-.01(.00)$ & $-2.89 * *$ \\
\hline Education & $-.11(.05)$ & -2.22 & $.00(.04)$ & -.02 & $.07(.05)$ & 1.62 \\
\hline Family Income & $.08(.01)$ & $5.50^{* * *}$ & $.04(.01)$ & $3.13^{* *}$ & $.04(.01)$ & $3.25^{* *}$ \\
\hline Employment & $.04(.09)$ & .43 & $.05(.07)$ & .63 & $-.03(.08)$ & -.37 \\
\hline Ln(ReadingNewspaper+1) & $.13(.04)$ & $3.61^{* * *}$ & $.07(.03)$ & $2.29 *$ & $.22(.03)$ & $6.50^{* * *}$ \\
\hline Ln (WatchingTv+1) & $.09(.04)$ & $2.33^{*}$ & $.10(.03)$ & $3.22 * *$ & $.08(.04)$ & $2.07 *$ \\
\hline Ln (SurfingontheWeb+1) & $-.08(.04)$ & $-2.08 *$ & $-.06(.03)$ & -1.77 & $-.25(.04)$ & $-6.60 * * *$ \\
\hline Social Media Use & $.12(.02)$ & $7.96^{* * *}$ & $.03(.01)$ & $2.20^{*}$ & $.03(.01)$ & $2.30 *$ \\
\hline Political Interest & $.63(.03)$ & $19.50^{* * *}$ & $.53(.03)$ & $20.05^{* * *}$ & $.59(.03)$ & $19.33 * * *$ \\
\hline Social Media Use $\times$ & $.04(.01)$ & $3.41^{* *}$ & $.03(.01)$ & $3.13^{* *}$ & $.03(.01)$ & $2.62 * *$ \\
\hline
\end{tabular}

Note. ${ }^{*} p<.05 ; * * p<.01 ; * * * p<.001$ 
Table 4

Results of Multiple Linear Regression Analyses on Social Media Use and General Trust in People

\section{Dependent Variable}

\begin{tabular}{|c|c|c|c|c|c|c|}
\hline \multirow{3}{*}{ Explanatory Variable } & \multicolumn{2}{|c|}{ Online Public Discourse } & \multirow{2}{*}{\multicolumn{2}{|c|}{$\begin{array}{c}\text { General Public } \\
\text { Discourse }\end{array}$}} & \multirow{2}{*}{\multicolumn{2}{|c|}{ Civic Engagement }} \\
\hline & & & & & & \\
\hline & $\mathrm{B}(S E)$ & $t$ & $\mathrm{~B}(S E)$ & $t$ & $\mathrm{~B}(S E)$ & $t$ \\
\hline Gender & $.07(.07)$ & .95 & $-.10(.06)$ & 1.67 & .01(.06) & .22 \\
\hline Age & $-.01(.00)$ & $-3.05^{* *}$ & $.01(.00)$ & 1.45 & $-.00(.00)$ & -1.01 \\
\hline Education & $-.03(.05)$ & -.62 & $.07(.04)$ & 1.54 & $.14(.05)$ & $3.04 * *$ \\
\hline Family Income & $.10(.02)$ & $6.41^{* * *}$ & $.05(.01)$ & $4.22 * * *$ & $.05(.01)$ & $3.84 * * *$ \\
\hline Employment & $.02(.10)$ & .22 & $.03(.08)$ & .38 & $-.05(.09)$ & -.60 \\
\hline Ln(ReadingNewspaper+1) & $.25(.04)$ & $6.48^{* * *}$ & $.17(.03)$ & $5.37^{* * *}$ & $.31(.03)$ & $9.07^{* * *}$ \\
\hline Ln (WatchingTv+1) & $.13(.04)$ & $3.03^{* *}$ & $.14(.04)$ & $3.85^{* * *}$ & $.10(.04)$ & $2.65^{* *}$ \\
\hline Ln (SurfingontheWeb+1) & $-.05(.04)$ & -1.16 & $-.04(.04)$ & -.98 & $-.19(.04)$ & $-4.93 * * *$ \\
\hline Social Media Use & $.16(.02)$ & $9.86^{* * *}$ & $.06(.01)$ & $4.36^{* * *}$ & $.06(.01)$ & $4.17^{* * *}$ \\
\hline General Trust in People & $.30(.03)$ & $11.22 * * *$ & $.25(.02)$ & $11.80 * * *$ & $.40(.02)$ & $17.07 * * *$ \\
\hline Social Media Use $\times$ & $.00(.01)$ & .36 & $.02(.01)$ & $2.12^{*}$ & $.01(.01)$ & 1.26 \\
\hline
\end{tabular}

Note. ${ }^{*} p<.05 ; * * p<.01 ; * * * p<.001$ 
Table 5

Results of Multiple Linear Regression Analyses on Social Media Use and Life Satisfaction

\section{Dependent Variable}

\begin{tabular}{|c|c|c|c|c|c|c|}
\hline \multirow{3}{*}{ Explanatory Variable } & \multicolumn{2}{|c|}{ Online Public Discourse } & \multirow{2}{*}{\multicolumn{2}{|c|}{$\begin{array}{c}\text { General Public } \\
\text { Discourse }\end{array}$}} & \multirow{2}{*}{\multicolumn{2}{|c|}{ Civic Engagement }} \\
\hline & & & & & & \\
\hline & $\mathrm{B}(S E)$ & $t$ & $\mathrm{~B}(S E)$ & $t$ & $\mathrm{~B}(S E)$ & $t$ \\
\hline Gender & $.16(.07)$ & $2.27 *$ & $.17(.06)$ & $2.91^{* *}$ & $.13(.06)$ & $2.14 *$ \\
\hline Age & $-.01(.00)$ & $-3.36^{* *}$ & $.01(.00)$ & $1 . .36$ & $-.01(.00)$ & -1.35 \\
\hline Education & $-.05(.05)$ & -1.05 & $.05(.04)$ & 1.21 & $.12(.04)$ & $2.75^{* *}$ \\
\hline Family Income & $.08(.02)$ & $5.28^{* * *}$ & $.04(.01)$ & $3.24 * *$ & $.03(.01)$ & $2.33^{*}$ \\
\hline Employment & $.02(.09)$ & .25 & $.04(.08)$ & .49 & $-.04(.08)$ & -.56 \\
\hline Ln(ReadingNewspaper+1) & $.19(.04)$ & $5.18^{* * *}$ & $.13(.03)$ & $4.33^{* * *}$ & $.24(.03)$ & $7.77 * * *$ \\
\hline Ln (WatchingTv+1) & $.12(.04)$ & $2.99 * *$ & $.13(.03)$ & $3.76^{* * *}$ & $.09(.04)$ & $2.60^{*}$ \\
\hline Ln (SurfingontheWeb+1) & $-.04(.04)$ & -.83 & $-.02(.04)$ & -.70 & $-.18(.04)$ & $-4.94 * * *$ \\
\hline Social Media Use & $.15(.02)$ & $9.36^{* * *}$ & $.05(.01)$ & $3.63^{* * *}$ & $.04(.01)$ & $3.14^{* *}$ \\
\hline Life Satisfaction & $.44(.03)$ & $16.07 * * *$ & $.34(.02)$ & $14.93 * * *$ & $.54(.02)$ & $23.49^{* * *}$ \\
\hline Social Media Use $\times$ & $.00(.01)$ & .19 & $.02(.01)$ & $2.38 *$ & $.02(.01)$ & $2.07^{*}$ \\
\hline
\end{tabular}

Note. ${ }^{*} p<.05 ; * * p<.01 ; * * * p<.001$ 